\title{
Aplikasi Analytical Hierarchy Process Pada Pemilihan Metode Analisis Zat Organik Dalam Air
}

\author{
Dino Rimantho ${ }^{1}$, Marrie Rachel ${ }^{2}$, Bambang Cahyadi ${ }^{3}$, Yan Kurniawan ${ }^{4}$
}

\begin{abstract}
Water is one of the food products analyzed in water chemistry and environmental laboratories. One of the parameters analyzed are organic substances. The number of samples that were not comparable with the analytical skills can cause delays in test results. Analytical Hierarchy Process applied to evaluate the analytical methods used. Alternative methods tested include titrimetric method, spectrophotometry, and total organic carbon (TOC). Respondents consisted of deputy technical manager, laboratory coordinator, and two senior analysts. Alternative results obtained are methods of TOC. Proposed improvements alternative analytical method based on the results obtained, the method of the TOC with a 10-15 minute analysis time and use of CRM to the validity of the analysis results.
\end{abstract}

Keywords. organic substance, analytical hierarchy process, titrimetric, spectrophotometry, total organic carbon.

\begin{abstract}
Abstrak. Air merupakan salah satu produk pangan yang dianalisis di laboratorium kimia air dan lingkungan. Salah satu parameter yang dianalisis adalah zat organik. Banyaknya sampel yang masuk tidak sebanding dengan kemampuan analisis dapat menyebabkan keterlambatan hasil uji. Metode Analytical Hierarchy Process diaplikasikan untuk mengevaluasi metode analisis yang digunakan. Alternatif metode yang diuji meliputi metode titrimetri, spektrofotometri, dan total organic carbon (TOC). Responden terdiri dari deputi manajer teknis, koordinator laboratorium, dan dua orang analis senior. Alternatif hasil yang didapat adalah metode TOC. Usulan perbaikan metode analisis berdasarkan alternatif hasil yang didapat, yaitu metode TOC dengan waktu analisis 10-15 menit serta penggunaan CRM untuk validitas hasil analisis.
\end{abstract}

Kata kunci: organic substance, analytical hierarchy process, titrimetric, spectrophotometry, total organic carbon.

\section{PEndahuluan}

Balai Besar Industri Agro (BBIA) merupakan institusi yang memberikan jasa pelayanan teknis

\footnotetext{
${ }^{1}$ Dino Rimantho, Jurusan Teknik Industri, Universitas Pancasila, Jl. Srengseng Sawah, Jagakarsa, Jakarta 12640 (email: dino.rimantho@univpancasila.ac.id\}

2 Marrie Rachel, Jurusan Teknik Industri, Universitas Pancasila, Jl. Srengseng Sawah, Jagakarsa, Jakarta 12640 (email: marrierachell@gmail.com).

${ }^{3}$ Bambang Cahyadi, Jurusan Teknik Industri, Universitas Pancasila, Jl. Srengseng Sawah, Jagakarsa, Jakarta 12640 (email: bambang.cahyadi@univpancasila.ac.id)

3 Yan Kurniawan, Jurusan Teknik Industri, Universitas Pancasila, Jl. Srengseng Sawah, Jagakarsa, Jakarta 12640 (email: yan96@yahoo.com)
}

Diajukan: 23-02-2016

Diperbaiki: 10-05-2016 kepada masyarakat industri, khususnya industri hasil pertanian.Salah satu layanan jasa yang diberikan oleh BBIA adalah layanan jasa pengujian mutu produk secara fisika, kimia, dan mikrobiologi. Laboratorium kimia air dan lingkungan adalah salah satu laboratorium di BBIA yang melakukan pengujian mutu produk air, salah satunya adalah parameter zat organik. Menurut SNI 01-3554-2006 mengenai cara uji air minum dalam kemasan, kandungan zat organik dapat ditetapkan melalui metode titrimetri, metode spektrofotometri, dan metode TOC. Ketiga metode tersebut memiliki perbedaan pada tahapan kerjanya.

Ketidakseimbangan antara jumlah sampel yang masuk dengan kemampuan analisis laboratorium menyebabkan keterlambatan hasil analisis, yang dapat memicu ketidakpuasan pelanggan. Di sisi lain, zat organik dapat ditetapkan dengan metode spektrofotometri dan dengan metode total organic carbon (TOC) 
dengan waktu analisis yang lebih cepat. Kareth (2012) menyatakan bahwa terdapat keterkaitan antara biaya dengan waktu pelaksanaan pekerjaan, dimana biaya langsung dapat meningkat apabila waktu pelaksanaan pekerjaan dipercepat. Akan tetapi, biaya langsung ini juga meningkat bila waktu pelaksanaan pekerjaan diperlambat. Sedangkan biaya tidak langsung tidak tergantung pada kuantitas pekerjaan, melainkan tergantung pada jangka waktu pelaksanaan pekerjaan. Bila biaya tidak langsung ini dianggap tetap selama umur proyek maka biaya kumulatifnya dapat naik secara linier menurut umur proyek (Fessenden \& Fessenden, 1986).

Berdasarkan studi pendahuluan yang telah dilakukan terdapat keterlambatan proses analisis dengan menggunakan metode konvensional (titrimetri) yang dapat mendorong terjadinya ketidakpuasan pelanggan dan tidak optimalnya biaya analisis. Oleh karena itu, diperlukan evaluasi terhadap pemilihan metode analisis zat organik menggunakan metode analytical hierarchy process (AHP) sebagai metode dalam pengambilan keputusan.

AHP adalah suatu proses rasionalitas sistemik. Dengan AHP dimungkinkan mempertimbangkan suatu persoalan sebagai satu keseluruhan dan mengkaji interaksi serempak dari berbagai komponen yang disusun secara berjenjang (hirarkis) sehingga mudah dipahami dan dianalisis.

AHP dapat digunakan untuk merangsang timbulnya gagasan untuk melaksanakan tindakan kreatif, dan untuk mengevaluasi keefektifan tindakan tersebut. Selain itu, untuk membantu para pemimpin menetapkan informasi apa yang patut dikumpulkan guna mengevaluasi pengaruh faktor-faktor relevan dalam situasi kompleks. AHP juga dapat melacak ketidakkonsistenan dalam pertimbangan dan preferensi peserta, sehingga para pemimpin mampu menilai mutu pengetahuan para pembantu mereka dan pemantapan pemecahan itu (Saaty \& Vargas, 1993).

Penerapan AHP telah dilakukan di sejumlah penelitian. Sebagai contoh, di Amerika Serikat dilakukan penerapan metode AHP dalam pengelolaan merkuri (Randall, dkk., 2004). Selanjutnya, studi yang dilakukan oleh Wang, dkk. (2009) mengaplikasikan metode AHP dalam rangka untuk mengurangi kompleksitas sistem pemilihan pengelolaan limbah padat. Selain itu, Rimantho dkk. (2015) mengusulkan metode AHP sebagai metodologi yang dapat diadopsi untuk menilai berbagai alternatif daur ulang limbah elektronik.

\section{Prinsip pokok AHP}

Dalam penggunaannya, AHP mengenal 3 (tiga) prinsip pokok, yaitu (Saaty, 1980):

1. Penyusunan hirarki. Penyusunan realitas yang kompleks kedalam bagian yang menjadi elemen pokoknya secara hierarkis (berjenjang).

2. Penentuan prioritas. Persepsi hubungan antara hal yang diamati, membandingkan hal yang serupa berdasar kriteria tertentu, dan membedakan kedua anggota pasangan itu dengan menimbang intensitas preferensi hal yang satu dibandingkan dengan yang lainnya. Hasil dari proses pembedaan ini adalah suatu vektor prioritas, atau relatif pentingnya elemen terhadap setiap sifat. Prioritas ini ditentukan berdasarkan pandangan para pakar atau pihakpihak terkait yang berkompeten terhadap pengambilan keputusan.

3. Konsistensi logis. Konsistensi berarti dua hal. Yang pertama, bahwa pemikiran atau obyek yang serupa dikelompokan menurut homogenitas dan relevansinya. Yang kedua adalah intensitas relasi antar gagasan atau antar obyek yang didasarkan pada satu kriteria tertentu, saling membenarkan secara logis. Proses ini dengan jelas menunjukan bahwa segi kuantitatif merupakan dasar untuk mengambil keputusan yang sehat dalam situasi kompleks, dimana kita perlu menetapkan prioritas dan melakukan perimbangan.

\section{Prosedur AHP}

Langkah-langkah atau prosedur yang harus dilakukan dalam metode AHP untuk pemecahan suatu masalah, yaitu:

1. Definisikan persoalan dan rincian pemecahan yang diinginkan

2. Struktur hirarki dari sudut pandang menyeluruh

3. Buatlah sebuah matrik banding berpasangan untuk kontribusi atau pengaruh setiap elemen yang relevan atas setiap kriteria yang 
berpengaruh yang berada setingkat diatasnya.

4. Dapatkan semua pertimbangan yang diperlukan untuk mengembangkan perangkat matriks dilangkah 3 .

5. Setelah mengumpulkan semua data banding berpasangan, prioritas dicari dan konsistensi diuji.

6. Laksanakan langkah 3, 4 dan 5 untuk semua tingkat dan gugusan dalam hierarki itu.

7. Gunakan komposisi secara hierarkis (sintesis) untuk membobotkan vektor-vektor prioritas itu dengan bobot kriteria-kriteria

8. Evaluasi konsistensi untuk seluruh hieraraki.

\section{Penyusunan struktur hirarki}

Hierarki merupakan alat mendasar dari pikiran manusia, melibatkan identifikasi elemen-elemen suatu persoalan, mengelompokan elemen-elemen itu kedalam beberapa kumpulan yang homogen, dan menata kumpulan-kumpulan ini pada tingkattingkat yang berbeda. Pada dasarnya ada dua macam hirarki, yaitu hirarki struktural dan hirarki fungsional. Pada hirarki struktural, sistem yang kompleks disusun ke dalam komponenkomponen pokoknya dengan urutan menurun menurut sifat struktural mereka. Sedangkan, hirarki fungsional menguraikan sistem yang kompleks menjadi elemen-elemen pokoknya menurut hubungan esensial mereka.

\section{Penyusunan prioritas}

Penyusunan prioritas dilakukan dengan mencari bobot relatif antar elemen sehingga diketahui tingkat kepentingan (preferensi) dari tiap elemen dalam permasalahan secara keseluruhan.Langkah pertama dalam menentukan susunan prioritas elemen adalah dengan menyusun perbandingan berpasangan, yaitu membandingkan dalam bentuk berpasangan seluruh elemen untuk setiap sub sistem hirarki dan kemudian ditransformasikan dalam bentuk matriks untuk analisis numerik.

Misalkan terdapat suatu sub sistem hirarki dengan satu kriteria $C$ dan sejumlah $n$ elemen di bawahnya, $A_{1}$ sampai $A_{n}$, seperti terlihat pada Gambar 1. Perbandingan antar elemen tersebut dibuat dalam bentuk matriks $n \times n$ atau matriks perbandingan berpasangan.

Nilai $a_{i j}$ adalah nilai perbandingan elemen $A_{i}$ terhadap elemen $A_{j}$ yang menyatakan hubungan : seberapa jauh tingkat kepentingan $A_{i}$ bila dibandingkan dengan $A_{j}$, seberapa banyak kontribusi $A_{i}$ terhadap kriteria $\mathrm{C}$ dibandingkan dengan $A_{j}$, seberapa jauh dominasi $A_{i}$ dibandingkan dengan $A_{j}$, dan seberapa banyak sifat kriteria $C$ terdapat pada $A_{i}$ dibandingkan dengan $A_{j}$.

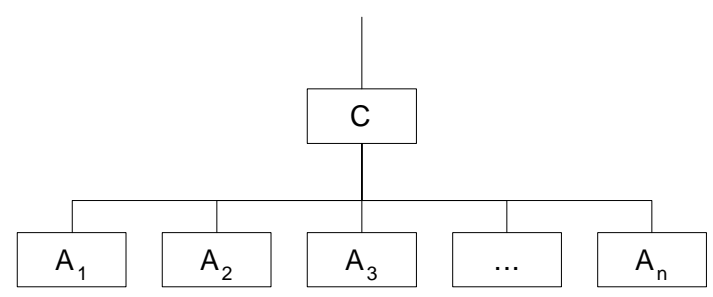

Gambar 1. Sub sistem hirarki (Saaty, 1993)

Tabel 1 menunjukkan bentuk matriks perbandingan berpasangan.

Tabel 1. Matriks Perbandingan Berpasangan

\begin{tabular}{cccccc}
$C$ & $A_{1}$ & $A_{2}$ & $A_{3}$ & $\ldots$. & $A_{n}$ \\
$A_{1}$ & $a_{11}$ & $a_{12}$ & $a_{13}$ & $\ldots .$. & $a_{1 n}$ \\
$A_{2}$ & $a_{21}$ & $a_{22}$ & $a_{23}$ & $\ldots .$. & $a_{2 n}$ \\
$A_{3}$ & $a_{31}$ & $a_{32}$ & $a_{33}$ & $\ldots .$. & $A_{3 n}$ \\
$\ldots$. & $\ldots$. & $\ldots$. & $\ldots$. & $\ldots$. & $\ldots$. \\
$A_{n}$ & $a_{n 1}$ & $a_{n 2}$ & $a_{n 3}$ & $\ldots .$. & $a_{n n}$ \\
\hline
\end{tabular}

(Sumber : Saaty, 1993)

Nilai numerik yang dikenakan untuk perbandingan di atas diperoleh dari skala perbandingan yang dibuat oleh Saaty (1993), ditunjukkan pada Tabel 2.

\section{Penilaian perbandingan multi partisipan}

Penilaian yang dilakukan oleh banyak partisipan akan menghasilkan pendapat yang berbeda satu sama lain. AHP hanya membutuhkan satu jawaban untuk satu matriks perbandingan. Oleh karena itu, Saaty (1993) memberikan metode perataan jawaban partisipan dengan geometric mean. Geometric mean theory menyatakan bahwa jika terdapat $n$ partisipan melakukan perbandingan berpasangan, maka terdapat $n$ jawaban (nilai) numerik untuk setiap pasangan. Untuk mendapatkan satu nilai tertentu dari semua nilai tersebut, masing-masing nilai harus dikalikan satu sama lain, kemudian hasil perkalian dipangkatkan dengan $1 / n$. Secara matematis dapat dituliskan seperti persamaan berikut : 
Tabel 2. Skala perbandingan nilai

\begin{tabular}{|c|c|c|}
\hline Tingkat & Definisi & Keterangan \\
\hline \multicolumn{3}{|l|}{ Kepentingan } \\
\hline 1 & Sama penting & Kedua elemen mempunyai pengaruh yang sama \\
\hline 3 & $\begin{array}{l}\text { Sedikit lebih } \\
\text { penting }\end{array}$ & $\begin{array}{l}\text { Pengalaman dan penilaian sedikit lebih memihak ke } \\
\text { satu elemen dibandingkan dengan pasangannya }\end{array}$ \\
\hline 5 & Lebih penting & $\begin{array}{l}\text { Pengalaman dan penilaian sangat memihak ke satu } \\
\text { elemen dibandingkan dengan pasangannya }\end{array}$ \\
\hline 7 & Sangat penting & $\begin{array}{l}\text { Satu elemen sangat disukai dan secara praktis } \\
\text { dominasinya sangat nyata dibandingkan dengan } \\
\text { elemen pasangannya }\end{array}$ \\
\hline 9 & $\begin{array}{l}\text { Mutlak lebih } \\
\text { penting }\end{array}$ & $\begin{array}{l}\text { Satu elemen terbukti mutlak lebih disukai } \\
\text { dibandingkan dengan pasangannya pada tingkat } \\
\text { keyakinan tertinggi }\end{array}$ \\
\hline $2,4,6,8$ & Nilai tengah & $\begin{array}{l}\text { Diberikan bila terdapat keraguan penilaian Antara } \\
\text { penilaian yang berdekatan }\end{array}$ \\
\hline Kebalikan & $a_{j i}=1 / a_{j i}$ & \\
\hline
\end{tabular}

(Sumber: Saaty, 1993)

$$
a_{i j}=\left(z_{1} \times z_{2} \times z_{3} \times \ldots \times z_{n}\right)^{1 / n}
$$

dimana:

$a_{i j}$ adalah nilai rata-rata perbandingan antara $A_{i}$ dengan $A_{j}$ untuk n partisipan.

$z_{i}$ adalah nilai perbandingan antara kriteria $A_{i}$ dengan $A_{j}$ partisipan ke-i.

$n$ adalah jumlah partisipan.

\section{Pengujian konsistensi}

Dalam persoalan pengambilan keputusan penting untuk mengetahui betapa baiknya konsistensi pengambil keputusan. Semakin banyak faktor yang harusdipertimbangkan, semakin sukar untuk mempertahankan konsistensi, ditambah lagi adanya intuisi dan faktor-faktor lain yang membuat orang mungkin menyimpang dari kekonsistensian.

Meskipun demikian sampai kadar tertentu perlu diperoleh hasil-hasil yang valid dalam dunia nyata. Saaty mengajukan indeks konsistensi untuk mengukur seberapa besar konsistensi pengambil keputusan dalam membandingkan elemen-elemen dalam matrik penilaian. Selanjutnya indeks konsisten ditransfer sesuai dengan orde atau ukuran matrik menjadi suatu rasio konsistensi. Rasio konsistensi harus $\leq 10 \%$, jika tidak pertimbangan yang telah dibuat mungkin akan acak dan perlu diperbaiki.

Pada matriks konsisten, secara praktis $\lambda \max =n$, sedangkan pada matriks tak konsisten, setiap variasi dari aij akan membawa perubahan pada nilai $\lambda \max$. Deviasi $\lambda \max$ dari $\mathrm{n}$ merupakan suatu parameter consistency index (CI), yang dinyatakan dengan :

$$
\mathrm{CI}=\frac{\lambda_{\max }-\mathrm{n}}{\mathrm{n}-1}
$$

Dari matriks random tersebut didapatkan juga nilai consistency index, yang disebut dengan random index (RI). Nilai RI dapat dilihat pada Tabel 3.

Tabel 3. Nilai random index

\begin{tabular}{cc}
\hline Orde Matriks & Random Indeks \\
1 & 0,00 \\
2 & 0,00 \\
3 & 0,58 \\
4 & 0,90 \\
5 & 1,12 \\
6 & 1,24 \\
7 & 1,32 \\
8 & 1,41 \\
9 & 1,45 \\
10 & 1,49 \\
\hline
\end{tabular}

(Sumber : Saaty, 1993)

Dengan membandingkan CI dan RI maka didapatkan patokan untuk menentukan tingkat konsistensi suatu matriks, yang disebut dengan consistency ratio (CR). Suatu matriks perbandingan adalah dinyatakan konsisten jika nilai $C R$ tidak lebih dari $0,10(C R \leq 0,10)$. 


$$
\mathrm{CR}=\frac{\mathrm{CI}(\text { Consistency Ratio })}{\mathrm{RI}(\text { Random Index })}
$$

\section{Pengujian konsistensi hirarki}

Prinsipnya adalah dengan mengalikan semua nilai consistency index $(C I)$ dengan bobot suatu kriteria yang menjadi acuan pada suatu matriks perbandingan berpasangan dan kemudian menjumlahkannya. Jumlah tersebut dibandingkan dengan nilai yang didapat dengan cara sama tetapi untuk suatu matriks random. Hasil akhirnya berupa suatu parameter yang disebut dengan consistency ratio of hierarchy $(C R H)$, dengan persamaan sebagai berikut:

$$
\mathrm{CRH}=\frac{\mathrm{CIH}}{\mathrm{RIH}}=\frac{\sum(\mathrm{CI} \times \text { Bobot Kriteria })}{\sum(\mathrm{RI} \times \text { Bobot Kriteria })}
$$

\section{Analisis sensitivitas}

Analisis sensitivitas dilakukan pada bobot prioritas dari kriteria keputusan, yang dapat terjadi karena adanya perubahan kebijaksanaan sehingga pembuat keputusan mengubah penilaiannya. Analisis sensitivitas dapat memprediksi keadaan apabila terjadi perubahan yang cukup besar. Misalnya terjadi perubahan penilaian bobot prioritas karena adanya perubahan kebijaksanaan sehingga akan menyebabkan berubahnya urutan prioritas alternatif dan berubah juga tindakan yang perlu dilakukan.

\section{Metodologi}

Jenis penelitian ini adalah penelitian deskriptif, yang bertujuan untuk membuat deskripsi atau gambaran secara sistematis, faktual dan akurat mengenai fakta-fakta, sifatsifat serta hubungan antara fenomena yang diteliti. Analisis data dilakukan dengan metode AHP.

Data yang digunakan pada penelitian ini adalah data primer dan data sekunder. Data primer dikumpulkan dengan menyebarkan kuesioner kepada responden yang merupakan para ahli yang memahami analisis zat organik dalam air. Responden berjumlah empat orang, yang terdiri dari Deputi Manajer Teknis, Koordinator Laboratorium Kimia Air dan Lingkungan, serta dua orang analis senior. Sedangkan data sekunder diperoleh dari studi literatur, pengamatan langsung, serta wawancara.

Metode AHP merupakan salah satu metode pengambil keputusan yang menguraikan suatu permasalahan kompleks dalam struktur hirarki dengan banyak tingkatan yang terdiri dari tujuan, kriteria, sub-kriteria, dan alternatif strategi. Pengolahan data dilakukan dengan bantuan software Expert Choice. Masukan dari Expert Choice adalah hasil perbandingan berpasangan yang dibuat berdasarkan struktur hirarki. Tahapan metode AHP yaitu: (1) menyusun hirarki yang terdiri dari kriteria uama, sub-kriteria dan alternatif strategi, (2) menyususn kuesioner AHP dengan uji banding berpasangan, (3) pengisian persepsi expert menggunakan skala 1 sampai 9. Kuesioner diisi oleh para ahli yang dianggap mengetahui pengembangan kebijakan operasional, (4) menghitung rataan geometrik dari $n$ responden, (5) memasukkan data rataan geometrik dalam matriks perbandingan berpasangan, (6) menguji konsistensi responden pada tiap matriks dan pada keseluruhan hirarki, (7) menghitung bobot prioritas pada kriteria, subkriteria dan strategi, (8) melakukan analisis sensitivitas

\section{HASIL DAN PEMBAHASAN}

Berdasarkan brainstorming dari pihak-pihak yang berkompeten, penelitian ini selanjutnya mengembangkan struktur hirarki. Terdapat tiga faktor pokok yang mempengaruhi pemilihan suatu metode analisis, yaitu waktu analisis, biaya analisis, serta jaminan hasil analisis. Waktu analisis yaitu waktu yang dibutuhkan untuk menganalisis sampel. Waktu analisis dibagi menjadi dua sub faktor, yaitu waktu preparasi dan waktu pengukuran. Biaya analisis adalah segala biaya yang dibutuhkan untuk menganalisis suatu sampel. Biaya analisis dibagi menjadi tiga subfaktor, yaitu biaya pereaksi, biaya peralatan, dan biaya operasional. Jaminan hasil analisis menjadi faktor yang penting untuk dijadikan pertimbangan pemilihan metode analisis, karena setiap analisis yang dilakukan harus dapat dijamin kebenaran data yang dihasilkan. Ada tiga subfaktor dalam jaminan hasil analisis, yaitu certified reference material (CRM), \% recovery, dan duplo. Hirarki faktor dapat dilihat pada Gambar 2. 


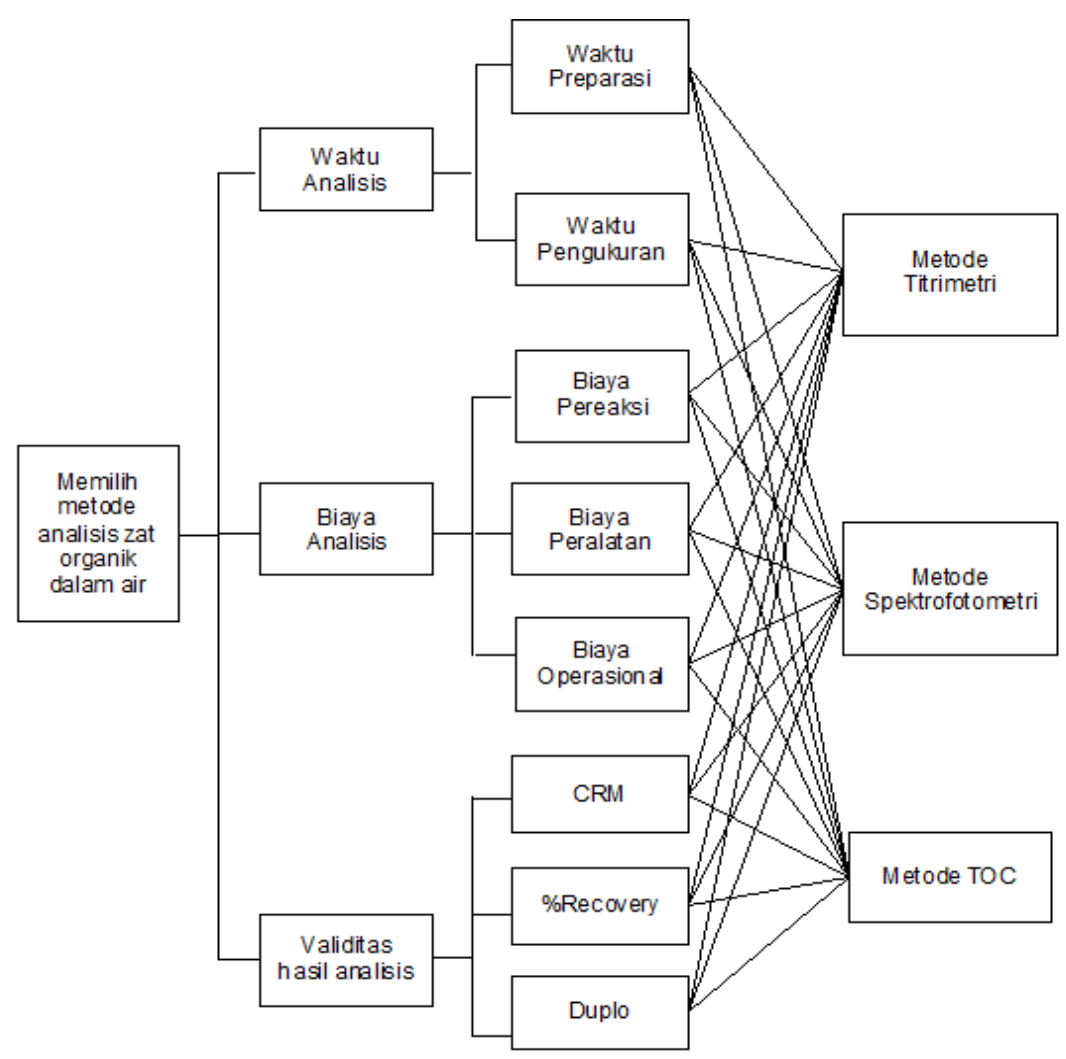

Gambar 2. Struktur hirarki pemilihan metode analisis zat organik dalam air

CRM adalah suatu cara yang dapat digunakan untuk penjaminan hasil analisis. CRM yang dimaksud adalah material yang berisi senyawa yang sama dengan senyawa yang dianalisis, yang telah diketahui kandungan senyawa di dalamnya secara pasti.

Recovery atau persen perolehan kembali adalah suatu cara yang digunakan untuk menjamin kebenaran hasil analisis yang didapat.

Duplo adalah pengerjaan sampel sebanyak dua kali secara bersamaan kemudian dihitung hasilnya. Bila hasil senyawa organik kedua pengerjaan tersebut tidak berbeda jauh (RPD kurang dari 10\%) maka hasil analisis dapat dijamin kebenarannya.

Berdasarkan perhitungan dengan Metode AHP didapatkan nilai consistency ratio of hierarchy $(C R H)$ sebesar 0,038 (lebih kecil dari 0,10), maka dapat dikatakan bahwa keseluruhan hirarki adalah konsisten, dan dapat dihitung bobot prioritas nya. Hasil pembobotan kriteria dapat dilihat pada Tabel 4.
Tabel 4. Hasil pembobotan kriteria

\begin{tabular}{lcc}
\hline \multicolumn{1}{c}{ Kriteria } & $\begin{array}{c}\text { Bobot } \\
\text { Kriteria }\end{array}$ & $\begin{array}{c}\text { Urutan } \\
\text { Prioritas }\end{array}$ \\
\hline Waktu analisis & 0.267 & 2 \\
Biaya analisis & 0.187 & 3 \\
Validitas hasil analisis & 0.546 & 1 \\
\hline
\end{tabular}

Menurut tingkat kepentingannya terhadap tujuan pemilihan metode analisis zat organik dalam air, kriteria validitas hasil analisis memiliki bobot tertinggi $(0,546)$ yang diikuti oleh kriteria waktu analisis $(0,267)$ dan kriteria biaya analisis $(0,187)$. Hal ini dikarenakan kriteria validitas hasil analisis adalah hal yang penting dalam suatu analisis. Hasil analisis yang valid adalah suatu keharusan dalam pemilihan metode analisis. Hasil pembobotan sub-kriteria dapat dilihat pada Tabel 5. 
Tabel 5. Hasil pembobotan sub kriteria

\begin{tabular}{lcc}
\hline \multicolumn{1}{c}{ Sub Kriteria } & $\begin{array}{c}\text { Bobot } \\
\text { Global }\end{array}$ & $\begin{array}{c}\text { Urutan } \\
\text { Prioritas }\end{array}$ \\
\hline Waktu preparasi & 0,099 & 3 \\
Waktu pengukuran & 0,168 & 2 \\
Biaya pereaksi & 0,064 & 6 \\
Biaya peralatan & 0,069 & 5 \\
Biaya operasional & 0,054 & 8 \\
CRM & 0,393 & 1 \\
Recovery & 0,093 & 4 \\
Duplo & 0,060 & 7 \\
\hline
\end{tabular}

Secara global, menurut tingkat kepentingannya terhadap tujuan pemilihan metode analisis zat organik dalam air, sub kriteria CRM memiliki bobot kepentingan tertinggi yaitu 0,393. Sub kriteria lain yang memiliki bobot cukup tinggi (di atas 0,1) adalah waktu pengukuran. Rasio konsistensi pada kriteria adalah kurang dari 0,10 . Artinya, secara umum, jawaban responden konsisten terhadap masing-masing sub kriteria dalam memilih sub kriteria CRM sebagai sub kriteria utama.

Berdasarkan nilai bobot hasil perhitungan tersebut di atas tampak bahwa faktor validitas hasil analisis menjadi faktor utama dalam pemilihan metode analisis zat organik, dengan sub faktor CRM. Hal ini disebabkan karena validitas hasil analisis adalah hal yang prioritas dalam suatu analisis. Hasil analisis yang valid adalah suatu keharusan dalam pemilihan metode analisis.

Sedangkan faktor waktu analisis menduduki urutan prioritas kedua dalam pemilihan metode analisis zat organik. Mengingat kondisi laboratorium serta banyaknya sampel yang diterima setiap hari menjadi pertimbangan utama. Sehingga metode analisis yang relatif cepat akan menjadi pertimbangan utama dalam pemilihan metode analisis, dengan sub faktor waktu pengukuran.

Kemudian urutan ketiga adalah faktor biaya analisis. Tersedianya dana yang jelas menjadikan faktor biaya analisis menjadi prioritas terakhir. Karena pada akhirnya biaya analisis tersebut akan dibebankan kepada konsumen. Sehingga faktor biaya analisis tidak begitu mempengaruhi pemilihan metode analisis. Hasil pembobotan strategi dapat dilihat pada Gambar 3.

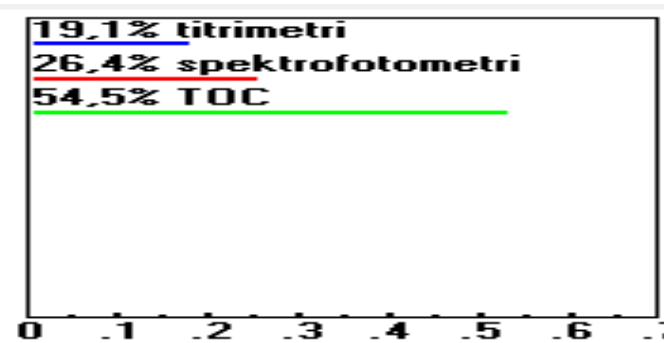

Gambar 3. Hasil pembobotan strategi

Hasil dari pembobotan strategi menunjukkan bahwa keempat responden memilih metode TOC. Metode ini dipilih sesuai dengan prioritas faktor penentu, yaitu faktor validitas hasil analisis yang diperoleh karena menggunakan CRM sebagai jaminan mutu hasil analisis, serta faktor waktu analisis yang cepat dengan waktu pengukuran maupun waktu preparasi yang lebih cepat dibanding metode titrimetri maupun metode spektrofotometri. Setelah dilakukan analisis sensitivitas, diketahui bahwa perubahan bobot faktor tidak mempengaruhi pemilihan strategi. Sehingga metode analisis yang dipilih tetap TOC.

Analisis sensitivitas dilakukan pada bobot prioritas dari kriteria keputusan, yang dapat terjadi karena adanya perubahan kebijaksanaan sehingga pembuat keputusan mengubah penilaiannya. Akibat terjadinya perubahan penilaian tersebut akan menyebabkan berubahnya urutan prioritas pada alternatif tujuan. Melalui analisis sensitivitas akan diketahui seberapa besar perubahan bobot yang akan mengubah urutan prioritas.

Model analisis AHP dapat digunakan untuk mengetahui kecenderungan pemihan strategi berda-sarkan perubahan pada setiap kriteria penentu pengembangan kebijakan opera-sional. Sensitivitas nilai dari masing-masing strategi dapat dilihat pada Gambar 4 untuk dinamic sensitivity dan Gambar 5 untuk performance sensitivity.

Gambar 5 menunjukkan informasi bobot tiap faktor yang mempengaruhi urutan prioritas pemilihan strategi. Bila bobot dari satu faktor diubah (dinaikkan maupun diturunkan) maka akan mempengaruhi bobot dari kedua faktor lain, serta dapat mempengaruhi bobot dari alternatif strategi. 


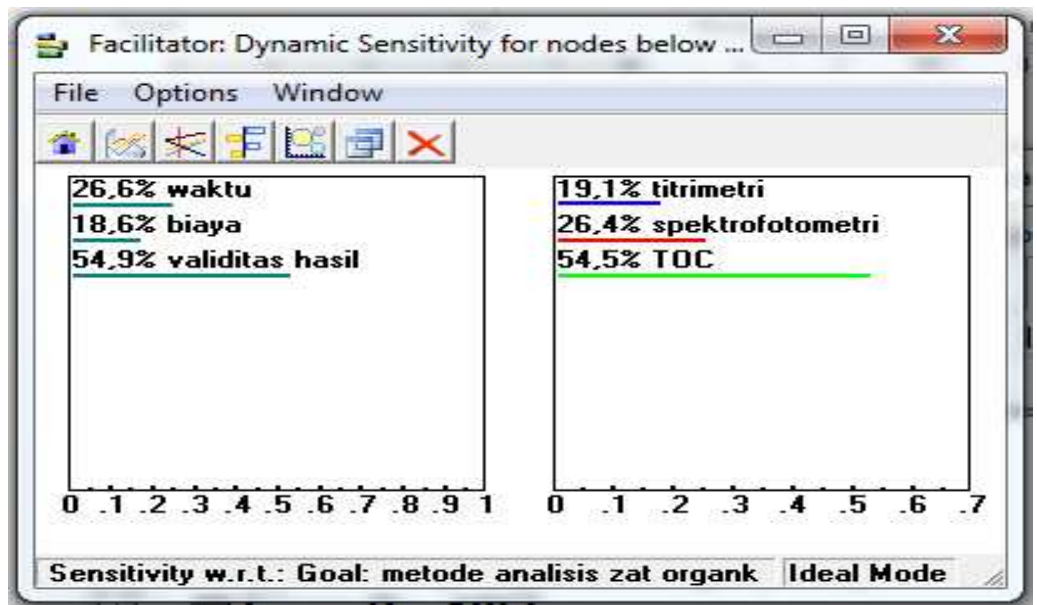

Gambar 4. Dinamic sensitivity dari strategi

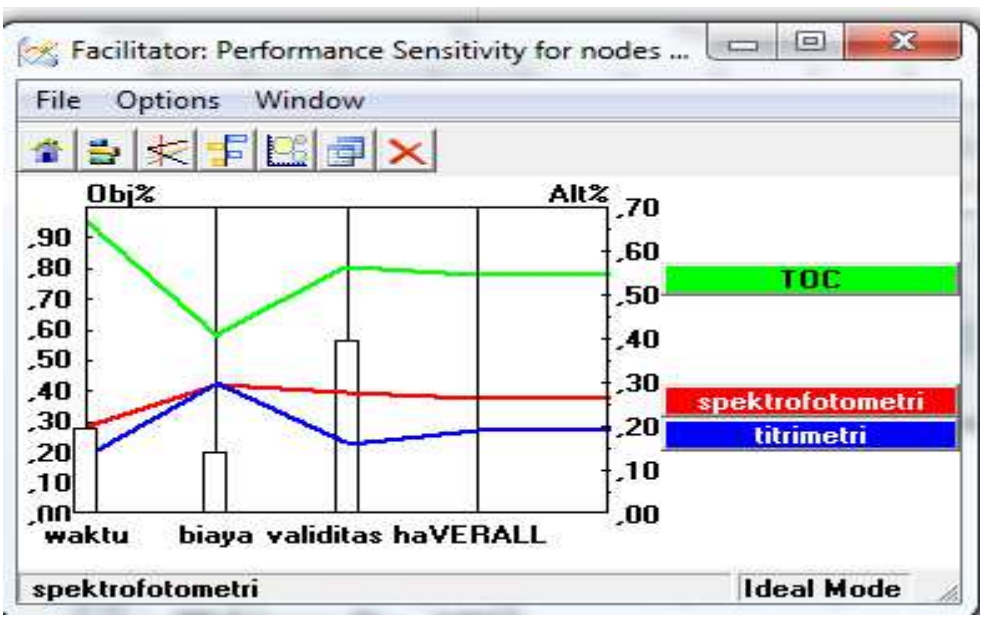

Gambar 5. Performance sensitivity dari strategi

Gambar 5 memberikan informasi terkait performance sensitivity dari alternatif tujuan, dimana hal ini menggambarkan kemungkinan terjadinya perubahan kondisi masing-masing faktor bila terjadi pergantian atau sejenisnya. Pada sumbu $x$ terdapat faktor yang membangun hirarki, sedangkan pada sumbu $y$ digambarkan nilai/bobot dari masing-masing faktor tersebut, serta urutan prioritas strategi. Bila bobot dari satu faktor diubah (dinaikkan maupun diturunkan) maka akan mempengaruhi bobot dari kedua faktor lain.

Dilakukan analisa sensitivitas yaitu dengan mengubah bobot nilai masing-masing kriteria sehingga didapat perubahan bobot nilai masingmasing kriteria, yang juga dapat berdampak pada perubahan urutan strategi/ alternatif tujuan.

Pada tahap ini dilakukan analisa sensitivitas dengan mengubah bobot nilai kriteria waktu analisis. Bobot prioritas saat ini untuk kriteria waktu analisis adalah $26,6 \%$. Setiap peningkatan $10 \%$ bobot kriteria waktu analisis, akan terjadi penurunan $2,6 \%$ pada kriteria biaya analisis, penurunan $7,6 \%$ pada kriteria validitas hasil analisis. Sehingga dapat menaikkan $1,7 \%$ strategi TOC. Namun untuk penambahan maupun pengurangan bobot kriteria waktu analisis, tidak mempengaruhi urutan prioritas strategi, yaitu strategi TOC masih menjadi prioritas pertama. Hal ini berarti bahwa jika kebijakan unit menginginkan adanya perubahan pada waktu preparasi serta waktu pengukuran dalam kriteria 
waktu analisis, tetap metode analisis TOC yang nanti akan diterapkan.

Pada tahap ini dilakukan analisa sensitivitas dengan mengubah bobot nilai kriteria validitas hasil analisis. Bobot prioritas saat ini untuk kriteria validitas hasili adalah 54,9\%, yang merupakan bobot kriteria yang paling besar. Setiap peningkatan $10 \%$ bobot kriteria validitas hasil analisis, akan terjadi penurunan $5,9 \%$ pada kriteria waktu analisis, dan penurunan $4,1 \%$ pada kriteria biaya analisis. Sehingga dapat menaikkan $0,3 \%$ strategi spektrofotometri dan $0,4 \%$ strategi TOC. Sedangkan untuk pengurangan $10 \%$ bobot kriteria validitas hasil analisis, adalah kebalikannya.

Dari analisis sensitivitas pada kriteria validitas hasil analisis, diketahui bahwa berapa pun besarnya perubahan pada kriteria, tidak mengubah urutan strategi yang digunakan. Metode TOC tetap berada di urutan pertama, karena bobot strategi tersebut sangat besar (lebih dari 50\%) sehingga perubahan kriteria tidak mempengaruhi urutan strategi metode TOC.

Ketiga metode dianalisis secara perbandingan bepasangan menggunakan metode AHP, diketahui bahwa faktor validitas hasil analisis adalah faktor yang paling mempengaruhi dalam pemilihan metode analisis, dengan bobot 0,546 . Sedangkan prioritas kedua dan ketiga yang mempengaruhi pemilihan metode analisis yaitu faktor waktu analisis dengan bobot sebesar 0,267 dan faktor biaya analisis dengan bobot 0,187. Berdasarkan analisa data pada sub faktor yang diteliti, menunjukkan bobot global kriteria yang mempengaruhi keputusan pemilihan metode analisis zat organik dalam air yaitu sesuai dengan kepentinganya adalah sub faktor CRM 0,393, sub faktor waktu pengukuran 0,168 , sub faktor waktu preparasi 0,099, sub faktor recovery 0,093, sub faktor biaya peralatan 0,069 , sub faktor biaya pereaksi 0,064 , sub faktor duplo 0,060 , dan sub faktor biaya operasional 0,054 .

Hasil dari penelitian menunjukkan bahwa strategi metode analisis yang dipilih adalah metode TOC. Metode ini dipilih sesuai dengan prioritas faktor penentu, yaitu faktor validitas hasil analisis yang diperoleh karena menggunakan CRM sebagai jaminan mutu hasil analisis, serta faktor waktu analisis yang cepat dengan waktu pengukuran maupun waktu preparasi yang lebih cepat dibanding metode titrimetri maupun metode spektrofotometri. Setelah dilakukan analisis sensitivitas, diketahui bahwa perubahan bobot faktor tidak mempengaruhi pemilihan strategi. Sehingga metode analisis yang dipilih tetap TOC.

\section{SIMPULAN}

Berdasarkan hasil penelitian dan pembahasan, dapat diperoleh kesimpulan hasil analisis berdasarkan preferensi responden terhadap metode analisis yang dianggap paling efektif adalah TOC. Hal ini didasarkan bahwa analisis menggunakan metode TOC membutuhkan waktu yang relatif singkat yaitu sekitar 10-15 menit. Metode ini dipilih sesuai dengan prioritas faktor penentu, yaitu faktor validitas hasil analisis yang diperoleh karena menggunakan CRM sebagai jaminan mutu hasil analisis, serta faktor waktu analisis yang cepat dengan waktu pengukuran maupun waktu preparasi yang lebih cepat dibanding metode titrimetri maupun metode spektrofotometri. Dengan waktu analisis yang lebih cepat dibanding metode titrimetri, maka kemampuan analisis akan lebih baik sehingga dapat meminimalisisr resiko keterlambatan hasil analisis. Selanjutnya, analisis sensitivitas dapat merubah urutan prioritas apabila terjadi perubahan variabel waktu, biaya, atau validitas hasil analisis.

\section{DAFTAR PUSTAKA}

Fessenden, R.J. \& Fessenden. (1986). Kimia Organik. Edisi Ketiga. (Terjemahan Aloysius Hadyana Pudjaatmaka, Ph.D). Jakarta: PT. Erlangga.

Kareth, M. (2012). 'Analisis optimalisasi waktu dan biaya dengan program Primavera 6.0 (Studi kasus: Proyek Perumahan Puri Kelapa Gading). Jurnal Sipil Statik, Vol. 1 (1), hal. 53 - 59.

Randall, P.; Brown, L.; Deschaine, L.; Dimarzio, J.; Kaiser, G.; Vierow, J. (2004). 'Application of the analytic hierarchy process to compare alternatives for the long term management of surplus mercury.' Journal of Environment Management, Vol. 71, pp. 35 - 43.

Rimantho, D.; Cahyadi, B.; Dermawan, D. (2015). 'Application analytic hierarchy process (AHP) by utilizing the Expert Choice as a tool in decision-making: a case study of e-waste management in Surabaya, Indonesia'. Proceeding 8 th International Seminar on Industrial Engineering and Management, Malang, Jawa Timur.

Saaty, T.L. (1980). The Analytic Hierarchy Process. New York, USA: McGraw-Hill.

Saaty, TL.; Vargas, L.G. (1993). Models, Methods, Concept \& Aplications of The Analytic Hierarchy Process. 
Internationel Series in Operations Research \& Management Science. Second Edition. New York: Springer.

Wang, G.; Qin, L.; Li, G.; Chen, L. (2009). 'Landfill site selection using spatial information technologies and AHP: a case study in Beijing,' China. Journal of Environment Management, Vol. 90, pp. 2414 - 2421. 